\title{
Kajian Pengembangan Usahatani Padi Organik SRI (System of Rice Intensification) Berwawasan Agribisnis dalam Mendukung Program Ketahanan Pangan Secara Berkelanjutan
}

\author{
Tarya J Sugarda, Anne Charina, Lisye Setiagustina, dan Iwan Setiawan \\ Jurusan Sosial Ekonomi Pertanian, Fakultas Pertanian, Universitas Padjadjaran \\ Jatinangor, Bandung 40600
}

\begin{abstract}
Assessment of the development of agribusiness-based organic farming system using System of Rice Intensification (SRI) in supporting sustainability of food safety program
\end{abstract}

The aim of this research was to formulate the on-farm and off-farm integration alternatives on agribusiness system to create sustainable development pattern of SRI in West Java. Through interview and comparative analysis to organic paddy farmers in Kabupaten Ciamis, Tasikmalaya, and Sukabumi, it was found that: 1) Spatially, the pilot project of SRI was only concentrated on the Southern part of West Java; socially, the majority of farmers were not well informed about the SRI techniques; economically, the SRI method was more profitable compared to the conventional one when the farmers produce their own organic fertilizer; ecologically, this method made the soil condition better than the condition in conventional method; technically, the farmers considered this method was very complicated, therefore the application was only in trial level with exception of a few farmers; 2) The SRI method was considered to be in a rash socialized and pseudo oriented; 3) The SRI method development had not supported yet by the legal regulation; 4) The paddy organic farming way that was considered to be weak, conventional method dependency, lack of motivation, lack of fertilizer supply, limited role of farmer group and facilitator agent, limited SRI information, and the weakness of the organic paddy marketing, affected the development of SRI paddy; 5) The strategies to overcome those facts are: produce more practical and larger scale of organic fertilizer, implement the rice estate and corporate farming management based on farmers group, integrate the SRI method with agribusiness of animal husbandry, strengthen the social capital (e.g. animal breeding and cooperative culture), integrate the organic paddy's market, arise the land rehabilitation program, and develop young aged, educated, and sustainable oriented farmers.

Key words: Work performance development, SRI organic paddy, food security, sustainability

\section{ABSTRAK}

Tujuan penelitian ini adalah merumuskan alternatif pengintegrasian on farm dengan off farm dalam sistem agribisnis untuk mewujudkan pola pengembangan SRI secara berkelanjutan di Jawa Barat. Melalui wawancara dengan pelaku padi organik di Kab. Ciamis, Kab. Tasikmalaya, dan Kota Sukabumi, serta analisis perbandingan, diperoleh beberapa temuan: 1) Secara spasial, pilot project SRI masih terkonsentrasi di zona ekologi Jawa Barat bagian selatan. Secara sosial, mayoritas petani belum mengetahui informasi dan teknis SRI. Secara ekonomis, jika input organik diproduksi sendiri, metode SRI lebih menguntungkan dibandingkan dengan metode konvensional. Secara 
ekologis, dengan metode SRI, tanah menjadi lebih baik. Secara teknis, SRI dipandang rumit oleh petani, sehingga penerapannya masih berada pada tahap mencoba (trial) kecuali beberapa tokoh tani; 2) sosialisasi SRI berjalan terlalu tergesa-gesa dan orientasi yang bias (pseudo); 3) pengembangannya belum didukung payung hukum atau pemihakan politis; 4) perilaku bertani organik petani yang lemah, ketergantungan pada metode konvensional, kurangnya motivasi, kurangnya supply pupuk, belum berperannya kelompoktani, belum memadainya tenaga fasilitator, minimnya informasi SRI, dan lemahnya akses jaringan pemasaran padi organik berpengaruh terhadap perkembangan padi SRI; dan 5) strategi untuk mengatasi permasalahan di atas meliputi: memproduksi pupuk organik yang lebih praktis dalam skala besar; menerapkan manajemen rice estate dan corporate farming berbasis kelompok tani; mengintegrasikan metode SRI dengan agribisnis peternakan; menguatkan modal sosial (seperti budaya beternak dan kerjasama); mengintegrasikan pasar padi organik; menggulirkan program rehabilitasi lahan, dan mengembangkan petani-petani SRI yang berusia muda, berpendidikan, dan berwawasan lestari.

Kata kunci: Kinerja pengembangan, padi organik SRI, ketahanan pangan, keberlanjutan

\section{PENDAHULUAN}

Implementasi program intensifikasi dalam revolusi hijau telah terbukti memunculkan beragam permasalahan serius dalam subsistem usahatani (on farm) padi di Indonesia, - seperti menurunnya produktivitas lahan (leveling-off), tercemarnya lingkungan, teracuninya mahluk hidup, dan resurgensi pada berbagai organisme pengganggu tanaman (OPT) (International Food Policy Research Institute, 2003).

Fenomena kerusakan lingkungan dan munculnya berbagai kritik atas model pembangunan pertanian dengan input luar yang tinggi telah mendorong berkembangnya dan memasyarakatnya pertanian ramah lingkungan. Pada kasus pangan, pengertian ramah lingkungan tidak hanya sekedar aman (bersih, sehat, bergizi, bermutu, dan berwawasan lingkungan) tetapi juga memberikan jaminan kesejahteraan bagi petani dan ketersediaan pangan secara berkelanjutan. Pada perkembangannya, konsep pertanian ramah lingkungan diarusutamakan menjadi pembangunan pertanian berkelanjutan (sustainable agriculture development) (Soetrisno, 1997; Sulistyowati, 1999).

Salah satu program pembangunan pertanian ramah lingkungan yang mulai mendapat perhatian serius di Asia adalah System of Rice Intensitication (SRI). Secara empiris, SRI mulai dikembangkan di Madagaskar sekitar 20 tahun yang lalu sebagai respon atas menurunnya kesuburan lahan, langka dan tingginya harga pupuk kimia, serta suplai air yang terus berkurang. Saat ini, SRI telah dikembangkan di banyak negara, seperti Thailand, Philipina, India, China, Kamboja, Laos, Srilangka, Peru, Cuba, Brazil, Vietnam, dan Indonesia. SRI dikatakan organik, karena mulai dari pengolahan lahan, pemupukan hingga penanggulangan serangan OPT menggunakan bahan organik (Reijntjes dkk., 1992).

SRI masuk ke Indonesia tahun 1997 dan mulai dikembangkan di Jawa Barat pada tahun 2003. Produktivitas padi dengan metode SRI sangat menakjubkan, karena mencapai angka rata-rata 9-11 ton.ha $^{-1}$ atau bahkan lebih. Melalui SRI, produktivitas padi bisa lebih tinggi, pada panen perdana di Sukabumi, SRI mampu meningkatkan produkti tas padi hingga 9,4 ton.ha ${ }^{1}$. Selain' itu, SRI juga hemat dalam penggunaan bibit (93\%), hemat air irigasi $(50 \%)$, dan hemat pestisida (100\%). (Royan. 2005; Susanti dkk., 2003). International Federation. of Organic Agriculture Movements (2004), melaporkan bahwa metode SRI juga memberikan kontribusi terhadap kesehatan tanah, tanaman dan memelihara mikroba tanah yang beragam. sebagaimana dilaporkan di 13 negara yang sudah mempraktikannya.

Pada kenyataannya, penerapan SRI dihadapkan pada masalah dan kendala sosial, teknis, politis, budaya, dan kelembagaan. Secara sosial, SRI sulit diterima, apalagi diadopsi oleh para petani. Di Tasikmalaya ditemukan kasus yang sama, bahwa sebagian besar petani padi organik yang sebelumnya mendapatkan pelatihan SRI dan 'telah 
menerapkannya selama dua musim, kini sebagian besar kembali ke pendekatan konvensional (Royan, 2005). Secara teknis, SRI masih dinilai rumit oleh para petani. Secara kelembagaan, petani menghadapi kesulitan di dalam memasarkan hasil, karena jaringannya kurang terakses oleh para petani. Petani tidak mendapatkan bimbingan SRI yang efektif dan berkelanjutan dari pendamping atau fasilitator. Petani menghadapi kesulitan untuk mendapatkan pupuk organik dan bahan pupuk organik. Petani kurang mendapatkan dukungan sosial, baik dari keluarga maupun mayoritas petani di sekitarnya. Secara politis, pemihakan pemerintah sendiri masih setengah hati untuk melegalisasi pengembangan SRI.

Ketidaksesuaian antara harapan dan kenyataan sebagaimana diuraikan dalam paragraf di atas, diduga terjadi karena pengembangan SRI di Jawa Barat masih belum terintegrasi. Padahal, pendekatan sistem agribisnis menghendaki terjadinya integrasi atau sinergisme antara satu subsistem dengan subsistem lainnya. Untuk itu, diperlukan alternatif strategi bagi pengintegrasian kegiatan on-farm dengan of-farm (up-stream, downstream, and supporting institution) dalam sistem agribisnis untuk mewujudkan pola pengembangan SRI secara efektif, efisien, dan berkelanjutan. Agar dihasilkan rumusan strategi yang tepat, maka perlu terlebih dahulu diungkap kinerja penerapan SRI dan faktor-faktor yang mempengaruhinya.

\section{METODE PENELITIAN}

Penelitian dilakukan di Kab. Ciamis, Kab. Tasikmalaya, dan Kota Sukabumi Jawa Barat dengan menggunakan metode survey deskriptif (deskriptif survey method). Data-data yang berhasil dikumpulkan melalui studi literatur, studi kebijakan dan wawancara terhadap 90 responden selama delapan bulan, dianalisis dengan tiga pendekatan, yaitu analisis kinerja penerapan SRI (tabulasi frekuensi, tabulasi prosentase,dan analisis deskriptif), analisis faktor-faktor yang berpengaruh (path analysis), dan analisis strategi pengembangan SRI (SWOT analysis).

\section{HASIL DAN PEMBAHASAN}

Pada tahun 1997-an, SRI dikembangkan secara perorangan, terutama tokoh tani dan agen pembaharu di beberapa lokasi di Indonesia, diantaranya di Jawa Barat dan Nusa Tenggara Barat. Selanjutnya, SRI dilembagakan, terutama oleh para pengamat hama penyakit tanaman (PHPT), PPL dan KTNA yang telah lama menjadi instruktur SLPHT dan atau telah lebih awal mengikuti pelatihan SRI. Pelatihan SRI pertama kali dilakukan di Ciamis tahun 1999. Setelah itu, eskalasi penyebaran SRI di Jawa Barat mengalami percepatan, seperti ke Tasikmalaya, Garut, Bandung, Sukabumi, dan kabupaten lainnya. Penyebaran SRI semakin cepat seiring digulirkannya program pelatihan dan bantuan permodalan dari berbagai pihak.

Secara umum, sosialisasi dan percontohan SRI masih belum intensif dan merata ke setiap daerah, sehingga mayoritas petani di Jawa Barat belum mengetahuinya. Meskipun SRI sudah dianjurkan dan diprogramkan oleh dinas teknis di beberapa daerah, namun belum dilindungi. dengan payung hukum yang jelas. Hal ini terjadi karena belum adanya keyakinan, konsistensi, koordinasi, dan partisipasi semua pibak di dalam pengembangan padi organik SRI. Padahal, secara sosio-teknis, proses penyebaran SRI terus mengalami percepatan, bahkan mulai tergesa-gesa, bias emosional, bias orientasi, bias proyek, bias kepentingan pengusaha sarana produksi pertanian, dan bias elit. Akibatnya: 1) sosialisasi SRI terkonsentrasi pada target perluasan areal penanaman " (percontohan) dan target peningkatan jumlah petani peserta; 2) pada kenyataannya, setiap dilakukan upaya perluasan. areal dan peningkatan jumlah petani peserta ke suatu daerah, senantiasa diikuti dengan pengurangan luas areal dan jumlah pengadopsi SRI di daerah pengembangan sebelumnya; 3) percepatan pemasyarakatan SRI terjadi karena adanya bantuan dari pemerintah, pengusaha maupun donatur, baik berupa uang, input organik maupun pelatihanpelatihan; 4) sosialisasi SRI kurang disertai dengan upaya penguatan kapasitas kelembagaan pelayananinput organik maupun pemasaran. Akibatnya, para petani SRI hanus membeli pupuk organik dari pengusaha dengan harga yang mahal ( $R p$ 400,00 $\mathrm{Rp} 600,00 / \mathrm{kg}$ )); dan 5) pemasyarakatan SRI bersifat parsial, sehingga kelemahan-kelemahannya kurang tersosialisasikan.

\section{Kinerja Petani SRI di Jawa Barat}

Secara umum, usahatani SRI di Jawa Barat didominasi oleh petani muda $(60 \%)$. Hal ini terjadi karena tiga faktor, yaitu: 1) meskipun secara teknis rumit, namun secara ekonomis SRI memberikan keuntungan dan daya tarik yang tinggi; 2) pelatihan SRI di Jawa Barat lebih dititikberatkan kepáda para pemuda tani sebagai keinginan berbagai pihak untuk 
me-regenerasi petani; dan 3) petani muda relatif belum ketergantungan dengan input kimia dan memiliki sifat ingin mencoba. Dari total petani yang konsisten dengan SRI, 55\% adalah pemuda tani, sedangkan dari total petani yang berhenti dan atau tidak melaksanakan, proporsi pemuda masingmasing hanya $10 \%$ dan $16.7 \%$. Namun demikian, lebih dari setengah jumlah pemuda $(57,8 \%)$ hanya tamatan SD dan SMP. Secara umum, petani SRI yang kinerjanya kuat $(42,2 \%)$ terdiri atas para petani muda, beberapa tokoh tani dan petani yang berlahan luas (petani kaya). Petani SRI yang berpendidikan tinggi, relatif lebih konsisten menerapkan SRI.

Pada umumnya, para petani mendapatkan pengetahuan SRI dari pelatihan, penyuluh, KTNA dan dari sesama petani. Secara empiris, para petani sangat berpengalaman dalam berusahatani padi $(83,33 \%)$, namun pengalaman dengan metode SRI baru 0,5-6 tahun dan rata-rata 1,5-2 tahun. Petani dengan pengalaman di atas 3 tahun relatif konsisten menerapkan SRI. Sedangkan mayoritas petani SRI yang kembali ke metode konvensional rata-rata berpengalaman antara 0,5-1 tahun. Modal untuk usahatani diperoleh petani SRI dari diri sendiri, pinjaman atau bantuan. Petani yang menggunakan modal sendiri relatif lebih konsisten menerapkan SRI, sedangkan yang mendapatkan pinjaman atau bantuan, sebagian besar tidak konsisten. Modal sangat diperlukan terutama untuk biaya pupuk organik, apalagi sebagian besar petani belum memiliki sumber pupuk organik sendiri.

Sebagian besar $(86,7 \%)$ petani SRI di Jawa Barat tergolong dalam kelompok early adopter dan early majority dengan kinerja kurang kuat. Hanya 10 persen petani yang berstatus kuat dalam pengambilan kepurusan (inovator). Padahal sebagian besar $(66,7 \%)$ petani SRI berstatus sebagai pemilik penggarap. Secara kuantitatif, hanya $30 \%$ petani pemilik penggarap yang tidak konsisten menerapkan SRI. Sedangkan mereka yang kembali ke metode konvensional sebagian besar $(40 \%)$ berstatus sebagai penyakap. Luas lahan belum berpengaruh terhadap pengembangan SRI, karena rata-rata SRI dikembangkan pada luasan $0,14-0,25$ ha.

Disamping faktor coba-coba, sempitnya luasan lahan SRI juga terkait dengan terbatasnya ketersediaan sarana produksi (terutama pupuk), besarnya jumlah tenaga kerja, intensifnya pemeliharaan, dan belum terjaminannya pasar. Orientasi petani SRI pada umumnya $(60 \%)$ adalah coba-coba dan $40 \%$ berorientasi komersial. Dorongan melaksanakan SRI sebagian besar bersumber dari luar petani, seperti harga yang tinggi, bantuan modal, penyuluhan, dan pelatihan. Motif ekonomi jauh lebih tinggi dibandingkan dengan motif sosial dan ekologi. Secara kuantitatif, kemauan partisipasi petani untuk menerapkan pola SRI di Jawa Barat relatif kuat $(66,60 \%)$. Namun demikian, ketergantungan pada model usahatani konvensional. kurang praktisnya teknik budidaya SRI dan sulitnya mendapatkan pupuk kandang (organik) telah mengakibatkan lemahnya kesempatan dan kemampuan partisipasi petani.

\section{Kinerja Kelompok Tani SRI}

Metode pengembangan SRI di Jawa Barat dilakukan dengan pendekatan kelompok. Hingga kini terdapat sekitar 220 kelompoktani SRI dengan jumlah anggota sekitar 5.506 orang petani dan mengelola lahan sekitar 498,4 ha. Keberadaan kelompok SRI tidak terlepas dari keberadaan dan peran fasilitator atau penyuluh SRI.

Hingga 2006 di Jawa Barat terdapat sekitar 102 orang pendamping SRI. Secara umum, kelompok tani SRI di Jawa Barat masih lemah fungsinya dalam memberikan pelayanan informasi dan sarana produksi pertanian kepada anggotanya, dan apalagi dalam memperkuat posisi tawar petani. 'Namun demikian, beberapa kelompok tani yang dikoordinir oleh KTNA sudah mulai berperan didalam penampung hasil usahatani anggota (memasarkan), sebagai penyedia input organik (meskipun sifatnya hanya menjadi distributor) dan sumber informasi bagi anggota.

\section{Kinerja Sumber dan Media Informasi SRI}

Pengembangan SRI tidak terlepas dari keberadaan sumber informasi, dari 20 sumber informasi pertanian organik yang teridentifikasi, hanya sembilan (40\%) yang kinerjanya relatif kuat, yaitu penyuluh (pendamping SRD), sesama petani, KTNA, tengkulak, penjual sarana produksi pertanian organik, brosur/leaflet tentang pertanian organik, lembaga swadaya yang fokus pada padi organik, kelompok pengembang SRI Jawa Barat dan kelompok tani SRI.

Empat (20\%) sumber informasi teridentifikasi berkinerja lemah, yaitu: televisi, radio, lembaga keuangan dan pemerintahan desa. Keterbatasan jumlah, ruang dan gerak sumber informasi serta belum efektifnya peran media massa didalam pengembangan SRI telah mengakibatkan lambatnya proses sosialisasi SRI. Lebih jauh, hal itu 
telah mengakibarkan lemahnya akses sebagian besar petani terhadap informasi SRI.

\section{Kinerja dan Sifat Inovasi SRI}

Sebagai inovasi, diakui oleh para petani pengadopsi bahwa SRI dapat menghemat benih sampai $90 \%$ (dari $70 \mathrm{~kg} \cdot \mathrm{ka}^{-1}$ menjadi 7 kg.ha- ${ }^{-1}$ ), menghemat air sampai $50 \%$, meningkatkan produksi sampai $100 \%$ (dari 4-5 ton.ha ${ }^{-i} \mathrm{P}$ menjadi 7-10 ton.ha ${ }^{-1}$ ), meningkatkan kesuburan lahan, meningkatkan daya ikat tanah terhadap air, menghasilkan kualitas nasi yang baik, dan meningkatkan harga jual gabah. Jika dibandingkan dengan metode konvensional, maka metode SRI jauh lebih menguntungkan, apalagi jika pupuk organik dapat diproduksi secara mandiri. Namun demikian, metode SRI sangat kontradiktif dengan kebiasaan petani yang sudah terbiasa dengan metode konvensional. Secara teknis, SRI masih dipandang rumit oleh para petani, terutama pada tahap penanaman, pemupukan, penyiangan dan pemeliharaan.

\section{Kinerja Sosial Budaya yang Terkait dengan SRI}

Pertanian organik sudah sejak tahun 1960an tereduksi dari sistem sosial masyarakat pedesaan Jawa Barat. Oleh karena itu, keberadaan modal sosial tersebut sudah sangat tipis. Namun, secara spasial, terdapat perbedaan eksistensi nilai (modal) sosial antara masyarakat Jawa Barat bagian utara, tengah dan selatan. Kecenderungannya, masyarakat bagian selatan lebih kuat dibandingkan zona lainnya. Pada masyarakat bagian selatan, sebagian petani masih lekat dengan budaya beternak. Secara umum, kehadiran SRI berlawanan dengan kebiasaan mayoritas petani yang sudah ketergantungan terhadap input kimia. Oleh karena itu, tidak mudah bagi siapapun yang mengembangkannya, mungkin ditentang, baik oleh birokrasi, elit desa maupun petani. Nilai potensialnya, para petani di Jawa Barat mulai sadar akan dampak negatif dari input kimia, terutama terhadap penurunan kualitas fisik dan produktivitas lahan.

\section{Kinerja Kelembagaan Pendukung SRI}

Pada lingkup nasional, Jawa Barat merupakan pusatnya kelembagaan pertanian. Dari sekitar 14 kelembagaan pendukung pertanian yang teridentifikasi, hampir semuanya $(85,71 \%)$ memiliki daya dukung yang lemah terhadap SRI, termasuk kelembagaan penyuluhan. Secara fisik, kelembagaan pendukung memang tersedia $(42,93 \%)$, namun secara fungsional belum banyak berperan dalam pengembangan SRI. Secara umum, kelembagaan pendukung juga sudah bias model pertanian knnvensional. Sehingga perilaku dan budaya orangorang di dalamnyapun sama dengan para petani, yakni sulit menerima SRI. Peran lebih nyata ditampilkan oleh dinas pertanian, PPL, KTNA, dan Kelompok Pengembangan SRI. Sejak awal pengembangan SRI, sebagian dari mereka sudah menjadi motivator, inisiator dan fasilitator SRI serta berperan di dalam perintisan jaringan pemasaran. padi SRI di Jawa Barat.

\section{Kinerja Usahatani SRI di Jawa Barat}

Secara umum terdapat tujuh prinsip (kaidah) usahatani padi organik SRI yang. dikembangkan, yaitu: 1) pengolahan tanah dan pemupukan dengan kompos organik, 2) benih yang bermutu dan ditanam berumur muda, 3) benih ditanam tunggal dan langsung, 4) jarak tanam yang lebar, 5) pemupukan tidak dengan pupuk kimia, 6) penggunaan air yang efisien (macak-macak), dan 7) pengendalian hama dilakukan secara terpadu tanpa menggunakan pestisida dan bahan-bahan sincecis. Hasil kajian mengungkap bahwa hampir di setiap daerah di Jawa Barat, petani belum menerapkan secara ideal ketujuh prinsip SRI. Banyak faktor penyebabnya, antara lain: 1) terlalu rumit; 2) serangan hama penyakit sulit dikendalikan; 3) pupuk organik sulit diperoleh dan atau mahal; 4) pertumbuhan tanaman terhambat; 5) kurangnya pendampingan; 6) sifat petani selalu ingin mencoba; 7) intensifnya pemeliharaan; dan 8) kesibukan kerja di sektor lain.

Pada dasamya, para petani yang berusia tua masih memiliki pengetahuan tentang jenis tanaman untuk pestisida hayati untuk pengendalian berbagai jenis OPT dan cara membuatnya. Sedangkan para petani yang berusia muda sangat lemah pengetahuan tentang itu. Namun demikian, secara umum, para petani mendapatkan pengetahuan tentang mikroorganisme lokal (MOL) yang lebih lengkap dari pelatihan PET dan SRI, disamping dari penyuluh dan KTNA yang memperoleh akses terhadap buku-buku tentang pertanian organik (Tabel 2). 
Tabel 2. Penyediaan mikroorganisme lokal (MOL) yang digunakan oleh petani organik SRI.

\begin{tabular}{|c|c|c|c|}
\hline Kegunaan & Bahan-bahan & Cara membuat & Dosis per ha \\
\hline $\begin{array}{l}\text { Unsur } \mathrm{P} \text { dan } \mathrm{K} \\
\text { Tinggi }\end{array}$ & $\begin{array}{l}\text { Tulang ikan, buah- } \\
\text { buahan, air beras, } \\
\text { kelapa muda (air } \\
\text { nira) }\end{array}$ & $\begin{array}{l}\text { Tulang ikan dan buah-buahan ditumbuk halus. } \\
\text { Semuanya dicampurkan ke dalam air beras dan air kelapa } \\
\text { muda, lalu difermentasikan selama } 15-20 \text { hari, kemudian } \\
\text { disaring. Bahan siap digunakan. }\end{array}$ & $\begin{array}{l}1 \text { liter MOL } \\
\text { dicampur dengan } \\
10 \text { liter air }\end{array}$ \\
\hline $\begin{array}{l}\text { Zat Pengatur } \\
\text { Tumbuh (ZPT) }\end{array}$ & $\begin{array}{l}\text { Iwung, bonggol } \\
\text { pisang, air kelapa } \\
\text { (tebu), air beras }\end{array}$ & $\begin{array}{l}\text { Iwung dan bonggol pisang dicincang sampai halus, lalu } \\
\text { dicampurkan dengan air kelapa dan air beras, lalu } \\
\text { difermentasikan selama 15-20 hari, kemudian disaring. } \\
\text { Bahan siap digunakan. }\end{array}$ & $\begin{array}{l}1 \text { liter MOL } \\
\text { dicampur dengan } \\
7-10 \text { liter air }\end{array}$ \\
\hline $\begin{array}{l}\text { Mengobati } \\
\text { Tanaman Padi } \\
\text { yang Daunnya } \\
\text { Menguning/ } \\
\text { Memerah }\end{array}$ & $\begin{array}{l}\text { Kotoran hewan, } \\
\text { terasi, kepiting } \\
\text { sawah, air tebu (air } \\
\text { kelapa muda, air } \\
\text { nira), air }\end{array}$ & $\begin{array}{l}\text { Kotoran hewan direndam dalam air, sementara terasi dan } \\
\text { kepiting ditumbuk dan dicampurkan dengan air tebu dan } \\
\text { didiamkan selama } 3 \text { hari, setelah itu disaring dan kedua } \\
\text { ramuan itu dicampurkan. Ramuan siap digunakan. }\end{array}$ & $\begin{array}{l}1 \text { liter MOL } \\
\text { dicampur dengan } \\
10-14 \text { liter air }\end{array}$ \\
\hline Unsur $\mathrm{N}$ tinggi & $\begin{array}{l}\text { Daun kalikira, } \\
\text { bonggol pisang, air } \\
\text { nira (air kelapa } \\
\text { muda/air tebu) }\end{array}$ & $\begin{array}{l}\text { Daun kalikira dan bonggol pisang dicincang setelah itu } \\
\text { dicampurkan dengan air nira, dan didiamkan selam } 15 \\
\text { hari. Bahan siap digunakan. }\end{array}$ & $\begin{array}{l}1 \text { liter MOL } \\
\text { dicampur dengan } \\
7-10 \text { liter air }\end{array}$ \\
\hline Vitamin & $\begin{array}{l}\text { Buah-buahan yang } \\
\text { manis (pepaya, } \\
\text { jambu), air nira }\end{array}$ & $\begin{array}{l}\text { Buah-buahan dicincang dan dicampur dengan air nira dan } \\
\text { didiamkan selama } 3 \text { hari setelah itu dicampur dengan air. } \\
\text { Bahan siap digunakan. }\end{array}$ & $\begin{array}{l}1 \text { liter MOL } \\
\text { dicampur dengan } \\
10 \text { liter air }\end{array}$ \\
\hline $\begin{array}{l}\text { Sebagai } \\
\text { Protein/TSP }\end{array}$ & $\begin{array}{l}\text { Keong mas (telur } \\
\text { keong mas), air } \\
\text { kelapa muda }\end{array}$ & $\begin{array}{l}\text { Keong mas ditumbuk sampai halus dan dicampur dengan } \\
\text { air kelapa muda, dan didiamkan selama } 7 \text { hari. Bahan siap } \\
\text { digunakan. }\end{array}$ & $\begin{array}{l}1 \text { liter MOL } \\
\text { dicampur dengan } \\
7 \text {-10 liter air }\end{array}$ \\
\hline
\end{tabular}

Analisis Usahatani Padi Organik SRI di Jawa Barat

Dianalisiṣ secara ekonomi, usahatani padi organik dengan metode SRI jelas sangat menguntungkan. Pada luasan yang sama, biaya produksi usahatani padi organik memang lebih tinggi daripada usahatani padi anorganik. Namun demikian, dalam tingkatan luas lahan dan harga gabah yang sama, usahatani padi organik jauh lebih menguntungkan daripada padi non organik (Tabel 3).

Tabel 3. Perbandingan rata-rata analisis usaha tani padi organik metode SRI dengan padi non organik per hektar pada berbagai status petani.

\begin{tabular}{lcccccccccc}
\hline & \multicolumn{3}{c}{ Pemilik Penggarap } & \multicolumn{3}{c}{ Penyewa } & \multicolumn{3}{c}{ Penyakap } \\
\cline { 2 - 10 } & $\begin{array}{c}\text { Non } \\
\text { organik }\end{array}$ & $\begin{array}{c}\text { Organik } \\
\text { SRI }\end{array}$ & $\begin{array}{c}\text { Naik/ } \\
\text { turun } \\
(\%)\end{array}$ & $\begin{array}{c}\text { Non } \\
\text { organik }\end{array}$ & $\begin{array}{c}\text { Organik } \\
\text { SRI }\end{array}$ & $\begin{array}{c}\text { Naik/ } \\
\text { turun } \\
(\%)\end{array}$ & $\begin{array}{c}\text { Non } \\
\text { organik }\end{array}$ & $\begin{array}{c}\text { Organik } \\
\text { SRI }\end{array}$ & $\begin{array}{c}\text { Naik/ } \\
\text { turun } \\
(\%)\end{array}$ \\
\hline $\begin{array}{l}\text { Biaya } \\
\text { (Rp.) }\end{array}$ & 2.462 .200 & 5.297 .321 & 115 & 4.152 .200 & 6.509 .733 & 56 & 5.152 .200 & 9.325 .554 & 81 \\
\hline $\begin{array}{l}\text { Penerimaan } \\
\text { (Rp.) }\end{array}$ & 5.500 .000 & $10.439 .910 *$ & 90 & 5.500 .000 & 8.937 .982 & 62,5 & 5.500 .000 & 10.235 .190 & 86 \\
\hline $\begin{array}{l}\text { Keuntungan } \\
\text { (Rp.) }\end{array}$ & 3.037 .800 & 5.142 .589 & 69 & 1.397 .800 & 2.428 .249 & 80 & 347.800 & 909.636 & 161 \\
\hline R/C ratio & 2,23 & 1,99 & 10 & 1,32 & 1,38 & 4,5 & 1,07 & 1,09 & 1,9 \\
\hline
\end{tabular}

Proporsi biaya paling besar untuk usahatani SRI adalah pupuk organik $(48,40 \%)$ dan tenaga kerja $(33,18 \%)$. Sedangkan, proporsi biaya pupuk untuk usahatani anorganik hanya 8,32 persen. Inilah kendala utama yang dihadapi para petani (khususnya petani penyakap) yang sudah lemah budaya beternaknya. Keuntungan SRI, setiap musim terjadi penurunan penggunaan input rata-rata sebesar $11 \%$, sehingga peningkatan produktivitas diikuti dengan penurunan jumlah dan biaya pupuk organik: Hasil 
analisis pada berbagai musim dan status petani (Tabel 3) terlihat, meskipun RC rasio penyakap lebih kecil dari petani lainnya, namun usahatani SRI memberikan keuntungan kepada semua ragam pelaku pada berbagai musim. Keuntungan ini akan meningkat lebih besar jika saja petani mampu mengusahakan pupuk organik secara swadaya.

\section{Tingkat Adopsi Padi Organik SRI}

Secara umum, baru $30 \%$ petani Jawa Barat yang akses terhadap informasi SRI. Dari jumlah itu, $5 \%$ sudah mencoba dan menerapkan SRI, 10\% dalam tahap menilai dan $15 \%$ baru tahap sadar. Dari jumlah petani yang mencoba dan menerapkan, $5 \%$ konsisten menerapkan SRI sesuai kaidahnya, 15\% melakukan rekayasa (modifikasi) terhadap kaidah SRI, dan $75 \%$ kembali ke metode konvensional. Berdasarkan hasil wawancara, terungkap adanya sekitar lima kelompok petani yang menerapkan SRI dengan model yang bervariasi, yaitu: 1) petani yang baru menerapkan padi organik SRI sesuai dengan kaidah SRI. Petani ini umumnya ditemukan di daerah pengembangan (pilot project) baru dan di beberapa daerah pengembangan lama yang konsisten atau yang menjadi perpanjangan tangan pemodal; 2) petani yang menerapkan SRI secara terus menerus, baik karena kesadaran maupun adanya dorongan dari luar, tetapi dengan perlakuan yang berbeda, seperti: pupuk organik dicampur dengan pupuk kimia, pengendalian OPT menggunakan pestisida kimia, SRI hanya dilakukan pada musim-musim tertentu, pada musim tertentu luas lahan padi organik SRI dipersempit dan melakukan penanaman (tandur) dengan cara konvensional; 3) petani yang menerapkan padi organik SRI pada musim-musim tertentu, baik sesuai dengan kaidah SRI maupun dengan rekayasa; 4) petani yang menerapkan padi organik SRI pada saat ada bantuan saja; dan 5) petani yang menerapkan padi organik SRI hanya karena ingin mencoba (penasaran). Petani ini ada yang berlanjut, namun sebagian tidak lagi melakukannya.

Terdapat beberapa faktor yang menyebabkan petani tidak konsisten menerapkan SRI, diantaranya: 1) pengembangan SRI belum mendapat dukungan dan pengakuan penuh dari pemerintah pusat maupun daerah; 2) pengembangan SRI masih terkonsentrasi di zona ekologi bagian selatan dan tengah; 3) pengembangan SRI baru pada tahap ujicoba; 4) pengembangan SRI baru dilakukan oleh tokoh tani atau elit desa pada luasan yang sempit; 5) dalam menerapkan SRI, motivasi eksternal lebih tinggi dibandingkan dengan motivasi internal;
6) sebagian besar petani yang telah mengikuti pelatihan SRI baru sebatas mencoba (trial), mereka belum yakin atau perlu menilai; 7) proses pendampingan masih lemah, sehingga banyak petani pencoba yang kembali ke metode konvensional atau tidak patuh pada prinsip-prinsip SRI; dan 8) faktor teknis (rumit) masih menjadi hambatan bagi keberlanjutan pemasyarakatan SRI.

\section{Keragaan Pemasaran Padi Organik SRI}

Pemasaran merupakan faktor yang sangat besar pengaruhnya terhadap perkembangan SRI di Jawa Barat. Harga beras organik yang tinggi yang diarusutamakan oleh para pengembang SRI merupakan perangsang bagi para petani. Secara makro, pemasaran padi organik memiliki segmen tersendiri, yakni kelas menengah ke atas: Lokasi penjualan padi organik juga masih terbatas, seperti di supermarket, hypermarket dan toko-toko tertentu di tempat tertentu. Jaringan pemasaran padi organik sudah membentuk satu rantai dari daerah sampai ke kota besar (Gambar 1), hanya sifatnya masih tertutup. Oleh karena itu, bukan hal mudah bagi para petani atau pelaku pemasaran lainnya untuk menembus jaringan padi organik. Beberapa lembaga yang terlibat adalah petani, kelompoktani," KTNA, koperasi tani, bandar lokal, pedagang pengumpul tingka daerah, pedagang luar daerah, pedagang pengecer dan konsumen akhir yang menjalankan. fungsi pemasaran yang berbeda-beda (Tabel 4).

\section{Strategi Pengembangan Padi Organik SRI di Jawa} Barat

Berdasarkan uraia-uraian pada latar belakang hingga hasil dan pembahasan di atas, maka dapat dirumuskan strategi pengembangan padi organik di Jawa Barat dengan menggunakan matrix analisis SWOT (Tabel 5 dan Tabel 6).

Beberapa hal penting yang harus diperhatikan bagi kajian selanjurnya adalah: 1) berkembangnya pandangan di tingkat petani dan pengembang SRI bahwa penggunaan sebanyak apapun pupuk organik tidak akan berdampak negatif terhadap lahan dan tanaman; 2) petani merasakan adanya lonjakan dan resistensi OPT setelah menggunakan pestisida hayati selama 5-7 musim tanam; 3) petani dan pengembang yang semula berpandangan bahwa jenis dan varietas apapun akan berproduksi tinggi jika diusahakan dengan SRI, ternyata di lapangan para petani merasakan bahwa produktivitas yang tinggi baru tampak pada varietas Ciherang dan Sintanur, sedangkan untuk yang lain 
belum diujicoba. 4) lahan yang dipupuk secara organik ternyata adaptif dengan kekeringan, sehingga pada musim kemarau, meskipun pasokan air kurang, padi tidak meranggas dan tanah tidak cepat retak-retak; 5) petani dihadapkan pada kenyataan sulitnya mendapatkan pupuk organik, untuk itu penting untuk dikaji mengenai rantai pasok pupuk dan input organik lainnya serta kemandirian petani dan kelompoktani dalam menyelesaikan masalah tersebut; dan 6) petani banyak yang kembali ke metode konvensional, alasan kesulitan menjangkau jaringan pasar padi organik.

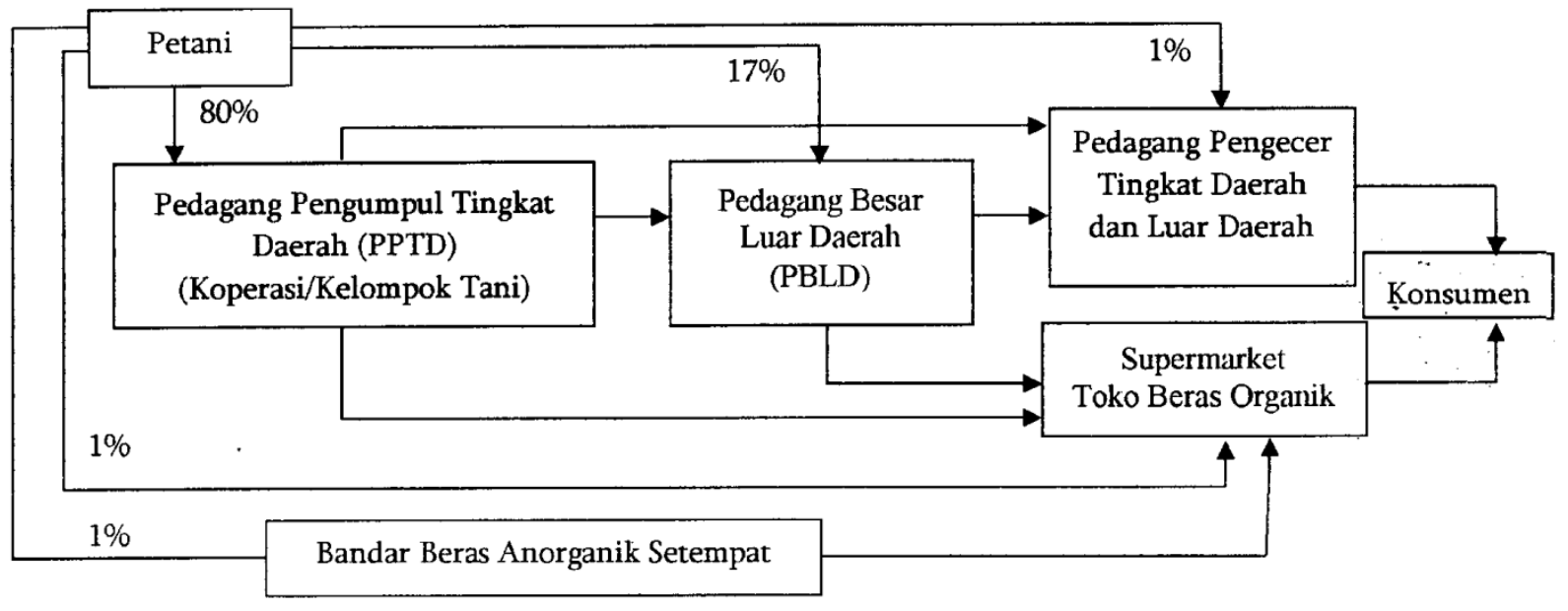

Gambar 1. Saluran pemasaran padi dan beras organik.

Tabel 4. Fungsi-fungsi yang dijalankan para pelaku dalam jaringan pemasaran padi dan beras organik.

\begin{tabular}{ll}
\hline \multicolumn{1}{c}{ Pelaku } & \multicolumn{1}{c}{ Fungsi yang dijalankan } \\
\hline Petani & Baru 60\% produk petani dijual dan 40\% dikonsumsi. \\
& Menjual ke KTNA (80\%) dan Menjual ke Bandar Beras Umum (20\%). \\
& Produk dijual dalam bentuk GKP dengan sistem jemput bola, baik ke KTNA maupun bandar. \\
& Harga yang diberlakukan oleh KTNA sebesar Rp 1.600,00/kg sampai Rp 1.800,00/kg. \\
& Harga yang diberlakukan oleh bandar umum sama dengan harga gabah umum (anorganik). \\
\hline Pedagang & PPTD umumnya KTNA yang menampung hasil dari para petani. Berlokasi di kabupaten. \\
Pengumpul & KTNA ini baru mampu memasok sekitar 1,5-2 ton/bulan. \\
Tingkat & PPTD menjalankan fungsi pembelian, pengolahan (mengeringkan dan menggiling gabah, sortasi, \\
Daerah & standardisasi dan mengemas beras), pengangkutan, penjualan, pertukaran, pelayanan informasi \\
(PPTD): & harga, pelayanan informasi pasar dan pengontrolan. \\
KTNA/ & Harga yang diberlakukan PPTD sebesar Rp 5.000,00/kg (Rp 25.000,00 /5 kg) untuk mutu A dan \\
Koperasi & Rp 4.500,00/kg (Rp 22.500,00/kg) untuk mutu B. \\
Tani & Biaya tataniaga berkisar antara Rp 850 1.000,00/kg. Margin pemasaran berkisar Rp 1.700,-- \\
& sampai Rp 2.200,00/kg. Keuntungan berkisar antara Rp 900,00 (mutu B) - Rp 1.500,00 (mutu A). \\
\hline Pedagang & PBLD adalah pasar yang dituju atau dipasok oleh PPTD. \\
Besar Luar & Berlokasi di Kota Bandung atau kota lain di luar Ciamis, Tasikmalaya dan Sukabumi. \\
Daerah & Transaksi dilakukan secara tunai (jika belum ada kerjasama) dan atau sistem tunda jual. \\
(PBLD) & PBLD melakukan fungsi penjualan di tempat dan atau mengirim langsung kepada konsumen. \\
& Harga yang diberlakukan adalah Rp 7.000,00/kg (Rp 35.000,00/5 kg eceran langsung) atau Rp \\
& 6.000,00/kg (Rp 30.000,00/5 kg jika dititipkan lagi ke pengecer). \\
& Biaya tataniaga berkisar antara Rp 75-100,00/kg. Margin pemasaran berkisar antara Rp 1.000,00. \\
& sampai Rp 2.000,00kg. Keuntungan berkisar antara Rp 900,00 (mutu B) - Rp 1.900,00 (mutu A). \\
\hline
\end{tabular}


Tabel 4. (lanjutan).

$\begin{array}{ll}\text { Pedagang } & \text { Pedagang pengecer pada umumnya melakukan fungsi penjualan. } \\ \text { Pengecer } & \text { Pedagang pengecer ada yang berlokasi di daerah dan di luar daerah (toko atau supermarket). } \\ & \text { Pengecer ada yang melakukan pengemasan ulang ada yang tidak. } \\ & \text { Harga terbentuk sebesar } \mathrm{Rp} 30.000,00 \text { sampai } \mathrm{Rp} 35.000,00 / 5 \mathrm{~kg} \text { (di tingkat daerah) dan } \mathrm{Rp} \\ & 40.000,00 \text { sampai Rp } 50.000,00 / 5 \mathrm{~kg} \text { untuk di Kota Bandung dan kota-kota besar sekitarnya. } \\ & \text { Pedagang pengecer berupa institusi (toko khusus, supermarket) atau perorangan. } \\ & \text { Biaya tataniaga berkisar antara Rp 250-500,00/kg. Rata-rata margin pemasaran berkisar antara } \\ & \text { Rp 2.000,00 sampai Rp 4.000,00/kg. Keuntungan rata-rata berkisar antara Rp 1.750,00 (untuk } \\ & \text { mutu B) hingga Rp 3.500,00 (untuk mutu A). }\end{array}$

Tabel 5. Analisis kekuatan dan kelemahan strategi pengembangan padi organik di Jawa Barat.

\begin{tabular}{|c|c|c|}
\hline Faktor & Kekuatan (Strength) & Kelemahan (Weakness) \\
\hline Faktor Internal & $\begin{array}{l}\text { 1.Pendapatan petani sebagian besar } \\
\text { diperoleh dari usahatani . } \\
\text { 2.Pengalaman beusahatani SRI petani } \\
\text { cukup lama ( } 2-3 \text { tahun). } \\
\text { Pengetahuan dan penguasaan SRI } \\
\text { dan PET cukup kuat . } \\
\text { 3.Penguasaan prasyarat partisipasi } \\
\text { petani tinggi, termasuk dalam } \\
\text { pertanian organik. } \\
\text { 4.Sebagian besar petani sudah } \\
\text { mengakui sebagai anggota kelompok } \\
\text { tani. } \\
\text { 5. Rata-rata usia petani SRI tergolong } \\
\text { muda. }\end{array}$ & $\begin{array}{l}\text { 1.Sebagian besar petani sangat } \\
\text { ketergantungan pada pupuk dan } \\
\text { pestisida kimia. } \\
\text { 2.Petani sudah terkontaminasi dengan } \\
\text { metode konvensional. } \\
\text { 3.Sebagian besar petani berusiá tua. } \\
\text { 4.Sebagian besar petani berlahan } \\
\text { sempit dan berstatus sebagai penyakap. }\end{array}$ \\
\hline Faktor Eksternal & $\begin{array}{l}\text { 6.Pengetahuan bahan untuk pupuk dan } \\
\text { pestisida organik relatif kuat. } \\
\text { 7.Pemahaman atas kerusakan lahan } \\
\text { akibat pupuk dan pestisida kimia } \\
\text { cukup kuat. } \\
\text { 8.Ada budaya beternak dan cenderung } \\
\text { didorong untuk berkembang. } \\
\text { 9. Masih ada budaya gotong-royong } \\
\text { atau kerjasama (kemitraan). }\end{array}$ & $\begin{array}{l}\text { 5.Sebagian besar petani lemah, } \\
\text { aksesnya terhadap informasi dan } \\
\text { inovasi pertanian ramah lingkungan. } \\
\text { 6.Lemahnya budaya beternak: } \\
\text { 7. Pertanian dipandang hanya sebagai } \\
\text { sampingan karena sibuk bekerja di } \\
\text { sektor lain. } \\
\text { 8.Komitment petani untuk } \\
\text { menerapkan SRI secara penuh masih } \\
\text { lemah. } \\
\text { 9.Orientasi petani SRI bias proyek } \\
\text { (semu). }\end{array}$ \\
\hline
\end{tabular}

Tabel 6. Strategi untuk menyiasati pemanfaatan peluang dan ancaman dalam mengembangkan padi organik di Jawa Barat.

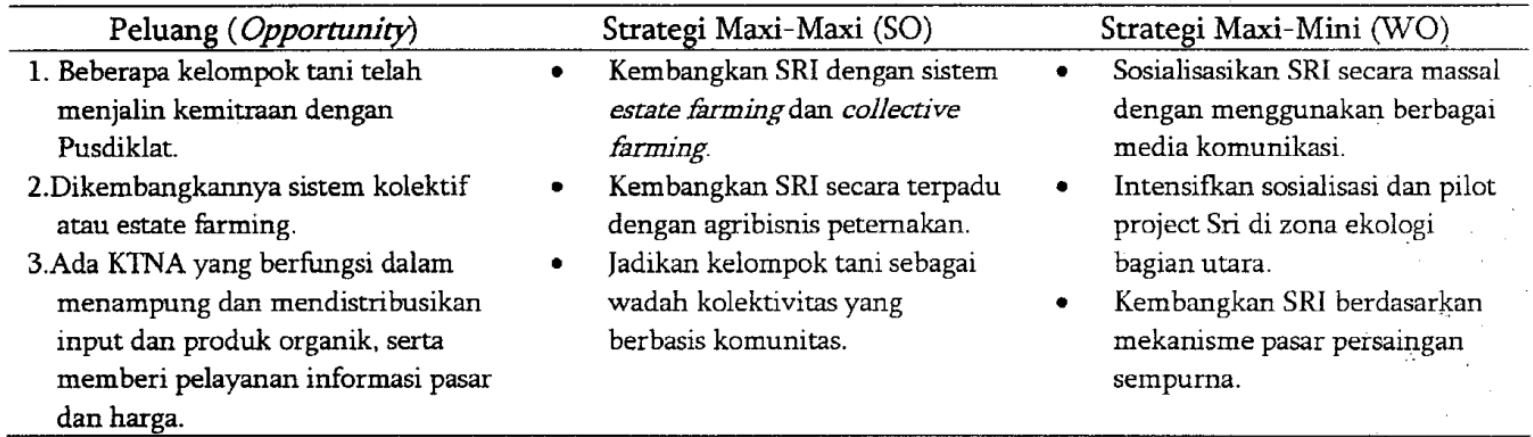


Tabel 6. (lanjutan)

\begin{tabular}{|c|c|c|}
\hline Peluang (Opportunity) & Strategi Maxi-Maxi (SO) & Strategi Maxi-Mini (WO) \\
\hline $\begin{array}{l}\text { 4.Terdapat perusahaan (swasta, } \\
\text { pemerintah dan swadaya) yang } \\
\text { memproduksi pupuk organik dan } \\
\text { pestisida hayati. } \\
\text { 5.Terdapat pusat penjualan produk } \\
\text { organik (toko dan supermarket). } \\
\text { 6.Banyak lembaga yang terlibat dan } \\
\text { menjadikan SRI sebagai salah satu } \\
\text { programnya. } \\
\text { 7.Ada asosiasi, KTNA dan jaringan } \\
\text { pemasaran padi organik. } \\
\text { 8.Ada program agribisnis peternakan } \\
\text { dan peningkatan IPM. } \\
\text { 9.Masih ada sedikit budaya bertani } \\
\text { organik, kecuali di Pantura. }\end{array}$ & $\begin{array}{l}\text { - Intensifkan pendampingan dan } \\
\text { tingkatkan jumlah tenaga } \\
\text { pendamping SRI agar terjaga } \\
\text { keberlanjutannya. } \\
\text { Kuatkan jaringan pemasaran } \\
\text { dan penyediaan input organik } \\
\text { di tingkat kelompoktani. }\end{array}$ & 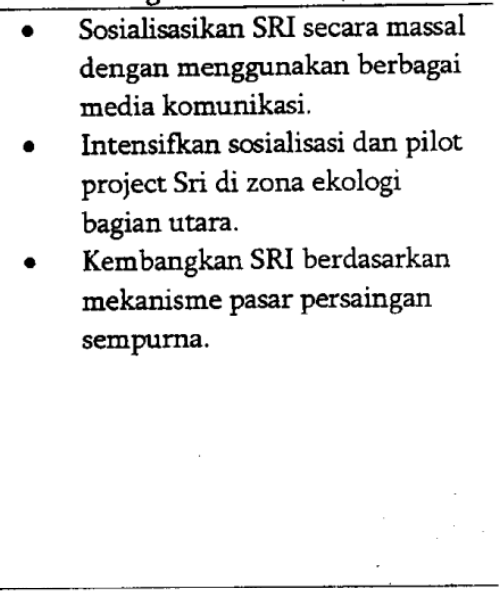 \\
\hline Ancaman (Treatment) & Strategi Mini-Maxi (ST) & Strategi Mini-Mini (WT) \\
\hline $\begin{array}{l}\text { 1. Mayoritas kelompok lemah } \\
\text { fungsinya, permodalannya dan } \\
\text { belum mampu menyediakan input } \\
\text { organik/ memasarkan hasil. } \\
\text { 2. Teknologi SRI belum praktis } \\
\text { (rumit). } \\
\text { 3. Konsumen beras organik masih } \\
\text { terbatas. } \\
\text { 4.Jaringan pemasaran masih terbatas, } \\
\text { belum sampai ke kelompok. } \\
\text { 5. Masyarakat sudah jauh dari budaya } \\
\text { organik dan beternak. } \\
\text { 6. Memudarnya budaya kerjasama dan } \\
\text { gotongroyong. } \\
\text { 7. Terbatasnya jumlah pendamping } \\
\text { SRI. } \\
\text { 8. Pemihakan pemerintah setengah } \\
\text { hati (SRI belum legal). } \\
\text { 9. Pendekatan masih keproyekan. }\end{array}$ & $\begin{array}{l}\text { 1. Kuatkan budaya beternak pada } \\
\text { masyarakat petani. } \\
\text { 2. Kembangkan dan ciptakan inovasi } \\
\text { baru dalam teknik penanaman, } \\
\text { pemupukan dan pemeliharaan. }\end{array}$ & $\begin{array}{l}\text { Kembangkan SRI pada kelompok } \\
\text { pemuda tani yang berwawasan lestari }\end{array}$ \\
\hline
\end{tabular}

\section{SIMPULAN DAN SARAN}

Penerapan SRI di Jawa Barat sebagian besar masih berada pada tahap mencoba (trial). Secara ekonomi, metode SRI lebih menguntungkan dibandingkan cara konvensional. Informasi SRI belum diterima oleh mayoritas petani. Metode SRI dipandang belum praktis (rumit). Wilayah penyebaran SRI masih terkonsentrasi di Jabar bagian selatan. Petani kesulitan dalam mendapatkan input organik dan memasarkan hasil. Pengembangan SRI berjalan terlalu cepat dengan orientasi lebih terfokus pada peningkatan daerah pengembangan, luas lahan dan jumlah petani peserta SRI. Dari total petani di Jawa Barat, hanya 5\% yang mengadopsi SRI dan hanya petani elit dan peminat SRI (10\%) yang konsisten menerapkan SRI. Umur petani yang tua, pendidikan non formal tentang pertanian organik yang rendah, pengalaman berusahatani konvensional yang tinggi, lahan yang sempit, status petani yang mayoritas penyakap, pendapatan yang tidak memadai, lemahnya (motivasi internal, budaya beternak, peran kelompoktani, pendamping (penyuluh SRI), informasi SRI, payung hukum atau kebijakan pemerintah, jaringan pemasaran) dan kurangnya dukungan modal sosial masyarakat merupakan faktor-faktor yang mempengaruhi kinerja penerapan SRI.

Strategi yang perlu diterapkan adalah: 1) mengembangkan SRI dengan pendekatan estate farming dan collective farming dengan manajemen pengelolaan berada dalam wadah kelompok tani; 2) 
mengembangkan SRI secara terpadu dengan agribisnis peternakan yang dikelola secara personal maupun kelompok; 3) memberdayakan kembali budaya beternak pada masyarakat; 4) mengembangkan SRI di zona ekologi Jawa Barat bagian utara secara bertahap dengan pola pupuk berimbang; 5) mengembangkan dan ciptakan inovasi baru dalam penanaman, pemupukan dan pemeliharaan SRI secara praktis agar tidak rumit dan menyita banyak waktu; 6) memperkuat jaringan pemasaran; dan 7) mengembangkan SRI lewat pemberdayaan petani-petani muda yang berpendidikan dan berwawasan lestari. Sebaiknya pemerintah mengeluarkan kebijakan tentang pengembangan padi organik dan pupuk organik. Perlu pengkajian lebih lanjut untuk melihat dampak penggunaan pupuk organik terhadap lahan dan dampak pestisida hayati terhadap OPT, lahan dan lingkungan. Perlu dikembangkan industri pupuk organik yang menghasilkan pupuk organik dalam skala besar dan praktis. Perlu dilakukan pengkajian tentang jaringan bisnis padi organik secara komprehensip. Perlu dikaji dan diujicoba penerapkan estate farming yang dikelola oleh kelompoktani (komunitas).

\section{DAFTAR PUSTAKA}

Food Policy Research Institute. 2003. Green Revolution: Curse or Bllessing. IFPRI. Washington DC. USA.

International Federation of Organic Agriculture Movements. 2004. Standar-Standar Dasar IFOAM. Diterjemahkan oleh $\mathrm{R}$ Sutono. UGM Press. Yogyakarta.

Susanti RDI, A Chatarina, SP Suswati, dan SPR Ignatia. 2003. Pemberdayaan Petani Perempuan dalam Penerapan Sistem Pertanian Lestari. Dioma. Malang.

Reijntjes, C, H Bartus, dan B Water. 1992. Pertanian Masa Depan. Kanisius. Yogyakarta.

Royan, MY. 2005. Prospek Keberlanjutan Usahatani Padi Organik dengan Menggunakan Metode Sistem Rancang Intensif (SRI). Skripsi. Fakultas Pertanian Universitas Padjadjaran. Tidak dipublikasikan.

Soetrisno, L. 1997. Kemiskinan, Perempuan, dan Pemberdayaan. Kanisius, Yogyakarta.

Sulistyowati, A. 1999. Pertanian Organik dalam Sejarah Peradaban. Wacana 17 Mei-Juni 1999. Jakarta. 